\title{
Identification of Leading Sectors in Increasing Economic Growth of Indonesia in Madiun City
}

\author{
Ridho Muarief ${ }^{1}$, Netty Lisdiantini ${ }^{2}$, Yosi Afandi ${ }^{3}$, and Muhyiddin Aziz ${ }^{4}$ \\ ${ }^{1,2,3,4}$ State Polytechnic of Madiun, Madiun, East Java, Indonesia \\ \{ridho.muarief@pnm.ac.id ${ }^{1}$, nettylisdiantini@pnm.ac.id², yosi_afandi@polinema.ac.id ${ }^{3}$, \\ muhyiddinaziz@pnm.ac.id $\left.{ }^{4}\right\}$
}

\begin{abstract}
Within the framework of regional economic development goals needed policy development based on regional characteristics (endogenous development), by exploiting the potential of local resources. Identification of potential economic sectors (base) is needed for the optimization process and the success of economic development, where the process of structural transformation is happening in it. This research aims to identify leading sectors that can be developed in Madiun City. The leading sector is the main sector which is expected to be a driving force for the economic growth of a region, because it is able to make a large, competitive contribution and is able to encourage the growth of other sectors, so it is very useful in directing development and achieving its goals. The study was conducted by comparing the sectoral economic performance of Madiun City with the same sectoral performance in the East Java region as the reference area, with reference to the secondary GDP data of Madiun City and East Java Province for an observation period of at least 5 years. The tools used for analysis are Location Quotient, Model Growth Ratio and Overlay. The consequences of this take a look at indicate that the Manufacturing sector; Transportation and Storage; Accommodation and Food Service Activities; info and Communication; Business Activities; Human Health and social service Activity, these economic sectors have dominant growth and large contributions and are leading sectors.
\end{abstract}

Keywords: Economic Growth; Leading Sector.

\section{Introduction}

Development is a continuous process with the ultimate goal of improving community welfare. Therefore, the development strategy must be able to spur economic growth and increase the quality of human resources. Based on these development objectives and strategies, the implementation of development must be directed at things that can improve the welfare of the community. Development is generally targeted on monetary development through efforts to growth economic increase. Growth is stopped by increasing per capita income, or what is popularly called the economic growth strategy. It is hoped that the increase in per capita income, the problems faced, such as unemployment, poverty and inequality in income distribution, can be resolved through what is known as the "trickle down effect".Economic development as part of development has various benchmarks, one of which is economic growth. excessive and sustainable economic growth is the principal circumstance and a necessity for the continuity of financial improvement and growing welfare[1]. Kutznet defines economic growth as an increase in the capacity in the long run of a country concerned to provide economic goods to its residents[2]. countrywide economic development can't be 
separated from economic development in smaller regions, namely regional economic improvement. Similar to national economic development, regional economic development has the aim of increasing the standard of living and welfare of the people in the regions. The increase in the acceleration of growth is inseparable from the regional potential, especially the economic potential which should be managed and empowered to suit its capabilities and prospects in the future. Economic development in an area can be implemented with the availability of potential resources in the form of natural resources, human resources, science and technology.

Development also has a close relationship with various factors, both those that support and hinder in producing this development. Therefore, the impacts faced by regions as a result of the economic situation will be different because each region has different potential sectors. The potential resources owned from one region to another are uneven or not uniform, therefore the use of resources to increase economic growth in each region is also different. Based on the theory of unbalanced growth (unbalanced growth) put forward by Hirschman, economic development is prioritized in the economic sector that is able to encourage and attract other economic sectors to grow and develop, without neglecting development in other economic sectors. In other words, economic development aimed at increasing the rate of economic growth should be directed or prioritized to the leading or leading sectors in the regional economy. Economic growth is a measure of a region's economy. Elevated and sustainable economic growth is the main condition or a necessity for the continuity of economic development and increasing welfare [1]. Economic growth is a process of increasing regional per capita income in the long term, and is one of the important objectives of macroeconomic policies to determine the progress and welfare of a regional economy.

Regional development theories generally discuss methods for analyzing the economy of a region. Development always has both positive and negative impacts. Therefore, indicators are needed as benchmarks for development implementation. According to Kuncoro [3] the key development indicators are basically classified into: (a) economic indicators; (b) social indicators. The variables covered namely an economic indicator consist of the dimension regarding economic growth then by capita income. The variables protected of convivial symptoms are the Human Development Index (HDI) the Quality Life Index then sordid indicators. To measure the success of a regional economic development, there are several indicators commonly used as a tool to measure the success of regional development. The indicator often ancient is the Gross Regional Domestic Product (GRDP) who perform stay aged so an indicator about usual pecuniary performance as a measurement about the progress concerning a region. Other indications consist of increase rates, per capita profits or changes of economic structure. permanency. Several problems, such as inequality of development between regions, inequality of per capita income between regions and mismatched pace of rural-urban development, are problems that reduce the value of successful development.

Nowadays, many countries are starting to pay attention not only to accelerating economic growth but more to improving the quality of growth itself. The emergence of a condition where economic growth is running fast without being matched by the distribution of income and improving the quality of life has succeeded in shifting the existing development paradigm. This fact seems to reinforce the belief that economic growth is a necessary but not sufficient for the development process [3]. In this situation the quantity and quality of growth are both essential, both of which are involved in a reciprocal relationship. When growth stagnates or declines, then the social and welfare dimensions also decline, which means that the way that growth is generated is very important. The quality of the growth process itself, not just its speed, has been shown to influence development outcomes. That is why 
exploration of this matter is so essential. In essence there is economic growth, not only in quantity but equally important-also in quality [4]. Development planning basically has three aspects of planning, namely (1) macro; (2) sectoral; (3) regional; all of which are arranged in one unit so that it is like a mirror so that each side reflects the other side. Thus, through regional development that is harmonious and integrated both between sectors and between sectoral development linked to efficient and effective regional development planning, it is hoped that it can achieve regional independence and progress that is evenly distributed throughout the country. Based on the description above, it is important to identify and analyze potential economic potential in Madiun City development planning by looking at the contribution of Madiun City's Gross Regional Domestic Product (PDRB), economic growth rate and sources of growth as well as its comparison with Indonesia's Gross Domestic Product (GDP) is very important to study. By knowing and identifying existing economic conditions, potentials and opportunities, it will provide a better basis for the preparation of a more focused regional development plan in Madiun City. This is expected to stimulate the creation of sustainable development and achieve regional independence. Derived from the background of the research, the specific research questions are as follows:

a. What are the leading sectors in Madiun City for the period 2015-2019?

b. What is the role of the leading sectors in the economy in Madiun City?

\section{Literature Review}

\subsection{Economic Development}

Economic development is commonly described so a procedure up to expectation causes a long-term enlarge of actual profits per capita over the population among a country, accompanied by way of improvements in accordance with the institutional system So that economic development must keep viewed as much a procedure and as it is interrelated yet influences each other the factors as end result into such economic development perform lie seen. Furthermore, economic development wishes according to keep considered as much an enlarge of through capita income, up to expectation is, the quantity regarding enlargement between GDP yet GRDP among an addicted yr exceeds the rate of population growth As an end result over this make bigger which is revenue, like intention keeps enhancements into the pecuniary good on the neighborhood yet modernization of the financial structure. Basically, the development process is not just an economic phenomenon, but has a broad perspective. In the development process, efforts were made aimed at changing the structure of the economy for the better. In the discussion of development theory, especially economic development, there are four approaches, namely: Linear growth theory, structural growth theory, international dependency revolution theory, and Neo-Classical Theory [2]. The term economic improvement is normally associated along monetary improvement in rising countries. Some economists explain that term as pecuniary increase accompanied by using adjustments of the structure or style about pecuniary pastime certain as much accelerating economic growth and the hassle over income assignment then acknowledged namely economic development is a growth adjunct change, namely economic development. Development achievements can be assessed in various ways and benchmarks, both with an economic approach and a non-economic approach. An assessment using an economic approach can be carried out based on a review of the income aspect. The benchmarks of prosperity, whatever the approach and from whatever angle of view, will generally be consistent. Therefore, although income review benchmarks are not the only yardstick, they are still relevant and the most commonly applied [5]. 


\subsection{Regional Economic Growth}

Economic growth is a long-term economic problem. According to the views of ace economists such as much Thomas Robert Malthus, Smith, David Ricardo then John Stuart Mill, even are four elements so have an effect on economic growth, particularly population, stock on metropolis goods, shore location or natural fortune then the stage concerning technological know-how aged durability [5]. Regional economic growth is an increase in the overall income of the people in the area, namely an increase in all added value that occurs. Regional income represents remuneration for production factors operating in the region (land, capital, labor, and technology), which means that it can roughly describe the prosperity of the area [6]. To encourage regional economic growth, it is necessary to determine regional development priorities. If the development priorities are not adjusted to the potential of each region, the existing resources have not been fully exploited or have not been fully utilized. This situation results in a slow process of economic growth in the region concerned, which in turn can lead to developmental gaps and lags in the development of the area compared to other regions [7].

\subsection{Regional Development Theory}

Regional development is a procedure by using as provincial governments or communities rule present sources and structure a tie-up pattern of local governments then the private sector to propagate recent jobs yet augment the development on economic activity (economic growth) among the region. And is a process of forming new institutions, alternative industries, and improving the capacity of the existing workforce to produce better products and services, identifying new markets, transferring knowledge, and developing new businesses. The foremost hassle among regional development is within improvement policies based of the uniqueness on the location worried by means of the use of the dynamic on human, institutional or physical resources regionally (regionally). This orientation leads in accordance with the taking regarding initiatives created beyond the region among the improvement procedure according to beget recent action opportunities yet incite economic activity. Each regional pecuniary development effort has the important goal regarding growing the range or sorts regarding labor possibilities because regional communities. In an effort to achieve this goals, provincial governments yet theirs communities have to mutually bust partial improvement initiatives. Therefore, local rule then community participation yet via the usage of existing sources ought to be in a position after calculation the potential resources wished to graph then advance the regional economy. Development within the regional scope does not always proceed as quickly and evenly as desired. Some regions achieved fast growth while other regions experienced slow growth. These regions do not experience the same progress due to a lack of available resources, a tendency for the role of capital (investors) to choose urban areas or areas that already have facilities in addition to unequal redistribution of revenue sharing from the central government to the regions [7].

A regional planner must have the ability to analyze the economic potential of his area. This is related to its obligation to determine the real sectors that need to be developed so that the regional economy grows rapidly on the one hand and on the other hand it is able to identify factors that result in low potential for certain sectors and determine priorities to overcome these weaknesses. After regional autonomy, each region has become more free in determining sectors / commodities that are prioritized for development. The ability of local governments to see which sectors have both advantages and disadvantages in their region is becoming increasingly important. Sectors that have advantages have better prospects for development and are expected to encourage other sectors to develop [6]. 
Regional economic development planning perform lie viewed as put one's cards on the table in imitation of enhance the use of publicly accessible assets among the vicinity then in accordance with improve the ability about the private region after effect charge because these assets of a accountable manner. Development financial system ones Effective and environment friendly dodge requires careful put one's cards on the table related to the uses over public yet private region resources, farmers, short entrepreneurs, cooperatives, vast entrepreneurs, and social agencies need to hold a role within planning. Through partial economic improvement planning, a vicinity can lie viewed as like a entire so an monetary soloist in who like are various elements as engage including certain another. Experts and economists recognize that market mechanisms are incapable of creating adjustmentsquickly if there is change and unable to create a fast growth rate, especially in developing countries like Indonesia, so that government intervention is needed. The importance of government intervention in regional development to prevent the effects of the market mechanism on regional development and to ensure that development and its results can be enjoyed by various existing regions.

The difference in the level of development between regions has resulted in the emergence of disparities between regions, namely the accumulation of economic activities in certain areas while in other areas it is increasingly left behind. Centralizing economic expansion in one area will have a detrimental effect on other regions, because the existing labor, capital and trade will move to the regions that carry out the expansion. From the understanding stated above, it can be said that if the economic process is left to the market mechanism it will have an unfavorable effect both for underdeveloped regions and for developed regions which in turn can disrupt overall economic stability. Government intervention is very important for regional planning and development, as well as to prevent the gap in prosperity and community dissatisfaction [8]. According to Arsyad [8], regional economic development planning has several implications, including:

a. Realistic economic development planning requires an understanding of the relationship between regions and the national environment, both horizontally and vertically, which are interrelated and cannot be separated.

b. Something that is good nationally is not necessarily good for the region and vice versa, something that is good for the national is not necessarily good for the region.

c. The institutional tools available for regional development such as administration, decision-making processes and authority are usually very different at the regional level from those available at the central level.

Therefore, effective regional planning must be able to make the best possible use of existing development resources and be truly achievable.

\subsection{Economic Basis}

The economic degenerated principle bases its digest as the rate over economic growth among a location is decided with the aid of the amount about increase between exports between so much region. Economic things to do are grouped into basic things to do then nonbase activities. Only fundamental things to do can pressure local economic increase. In Richardson's export base theory, at first it only includes pure exports into the definition of exports, but then the meaning of exports in exploration becomes a broader definition, namely exports not only mean goods and services sold for foreign or foreign purposes, but also include goods. and services purchased by people outside the region even though the transactions themselves are carried out in the area, local activities that serve tourism are also basic jobs because they bring in money from outside the region, as well as local activities in 
urban areas such as restaurants, workshops, wholesale businesses, and supermarkets that serve people from outside the region are also basic jobs, military dormitories are also usually categorized as base jobs because they are usually financed by the central government.In the sense that activities whose products are sold outside the region are basic activities while nonbasis activities are activities that serve the needs of the community in the area itself, whether the buyer or the source of the money comes from the region itself.

The economic degenerated idea states up to expectation the major determinant over pecuniary growth between a region is immediately associated after the assert for goods and functions out of outdoor the region. The boom of industries so use local resources, which include electricity or uncooked substances because of export choice grow regional wealth and originate job opportunities (job creation). The regional development strategy that has emerged is based on this theory, namely an emphasis on the importance of assistance to promote business fields that have national and international markets, by implementing policies that reduce restrictions on export-oriented companies in the region. According to Wardihan [9], every region wishes in accordance with seem to be at sectors and commodities so much have huge strong yet may be promoted quickly, both because about natural potential or because this sectors hold a competitive abilities in accordance with develop. This potential so including the same capital requirements the sector can supply larger delivered price yet perform a tremendous performance to the economy. In kilter because of the market according to stand guaranteed, the production ought to stand in a position in accordance with explain or remain capable according to contest among overseas markets. The development regarding that region intention inspire other sectors in conformity with strengthen hence as the economy so a entire do grow.

The economic base theory is based totally about the argue up to expectation the degree of economic growth on a region is determined by using the amount about increase between exports beyond to that amount region. Basically, export activities are every things to do each producing products yet presenting capabilities so deliver cash out of backyard the area who is also referred according to as like simple activities. Economic activities are grouped within foundation activities yet non-basis activities. Only primary things to do execute develop provincial monetary activity. Workers anybody are domiciled within certain area, however action or acquire money among every other place is blanketed of the definition of export. All other activities which are not basic activities are included in service activities or sectors, but in order not to create a wrong understanding of the meaning of service, they are referred to as non-basic sectors. The non-base sector (service) is to meet local needs. Due to its nature that meets local needs, the demand for this sector is strongly influenced by the rate of increase in local people's income. Therefore, the increase is in line with the increase in local people's income. Thus, this sector is tied to local economic conditions and cannot expand beyond the regional economic growth. On the basis of this assumption, the only sector that can increase the regional economy beyond natural growth is the basic sector [6]. The essence of the basic economic theory according to Arsyad [8] is to that amount the most important determinant over growth between the economy on a vicinity is at once related to the assert for fit-out or functions out of backyard the region. The manufacturing increase that utilizes provincial resources, which includes action and uncooked substances because of export desire grow regional appearance or beget assignment opportunities (job creation). The weakness concerning it mannequin is so such is primarily based regarding external, not intimate demand, as between flip desire government according to a absolutely high servitude of market militia each nationally yet globally. However, it model is at all beneficial because determining the balance within the types of industries then sectors wished with the aid of tribe after 
strengthen economic stability. The economic base approach is actually based on the opinion that what needs to be developed in a region is the ability to produce and sell these products efficiently and effectively. Furthermore, this model describes the economic structure of a region in two sectors, namely:

a. Base Sector, namely sectors or economic activities that serve both the domestic market and markets outside the region itself. This means that regions indirectly have the ability to export goods and services produced by the sector to other regions.

b. Non-Basis Sectors, namely sectors or activities that are only able to serve the regional market itself.

c. Based on this theory, the basic sector needs to be developed in order to spur economic growth in a region

\subsection{Leading Sector}

In economic sectors, like are sectors whose entity has played a main position within the economic development concerning a place due to the fact that bear benefits primarily based over secure criteria, particularly:

a. Leading sectors must be able to become the main driver of economic development. This means that the sector can make a significant contribution to increasing production, income and expenditure.

b. Leading sectors have a strong linkage impact, both forward and backward linkages with other leading sectors or with other economic sectors.

c. Leading sectors are capable in accordance with contend together with comparable sectors beyond vile areas among the national then global markets, each of phrases regarding production fees over so sector, manufacturing costs, situation attribute and ignoble aspects..

d. Regional leading sectors have linkages with other regions, both in terms of market potential and input of raw materials.

e. Leading sectors have technology that continues to improve, especially through technological innovation.

f. Leading sectors are able to optimally absorb qualified workers according to the production scale owned by the sector.

g. The leading sectors can usually last a relatively long time.

Furthermore, it knowledge develops via investment activities then will become the foundation about monetary activity. This is primarily based of what huge the function over the zone is into the regional economic system durability [10]. Defines that a leading sector is a sector that has a comparative advantage and competitive advantage with similar products from other regions and is able to provide great benefits. Defines that a leading sector is a sector that has high added value and production, has a large multiplier effect on other economies, and has a high demand for both local and export markets.

\subsection{Leading Sector Linkage with Regional Economy}

Leading sectors are sectors, some on which is influenced by the existence of endowment factors. Furthermore, it factor develops further through funding activities or becomes the foundation of economic activity. The criteria for lead sectors wish range widely. This is based totally over how many tremendous the position of the area is into the regional economy, including: first, the lead region has a high growth rate; second, the area has a relatively big work absorption rate; third, the zone has high inter-sectoral linkages each of the future and backward; fourth, that can additionally keep interpreted as like a succesful zone propagate 
score delivered so high according to sambodo in sambuari [11]. Regional economic development has the main objective concerning growing the quantity yet sorts on labor possibilities because local communities. In an anxiety in conformity with attain this objectives, regional governments yet theirs communities should collectively absorb the initiative in imitation of boost theirs regions. Therefore, local governments should undertaking in accordance with use present sources between the area as appropriate because of the benefit of the human beings at sizeable then motivate the economy in conformity with progress. One of the development goals is to expand economic growth, along high economic growth the benefits about the wider neighborhood pleasure without a doubt keep felt. An vital indicator in conformity with determine the financial condition concerning a area then region among a absolute duration is shown with the aid of the Gross Regional Domestic Product (GRDP) records on the region. Economic increase is some of the vital indications among inspecting financial development so much happens between a country. Economic increase suggests the amount after which pecuniary pastime will cause extra masses profits in a certain period. Besides the analysis of economic growth can be used to determine the success of the development that has been achieved, it can also be used to determine the direction of future development. The linkage between the leading sector and the economy, namely the leading sector is a gift factor where the superior sector has a comparative and competitive advantage where this advantage is a condition for a commodity to be able to compete in the market, if a commodity is able to compete in the market it will increase economic growth and make the economy of a region heading in a better direction.

\section{Research Methods}

In this study, the analysis used is in the form of descriptive analysis, which is a technique used to describe something in general and aims to facilitate explanation and usually through the interpretation of tables or graphs. Other analyzes used in this research are Location Quotient, Growth Ratio Model and Overlay, namely to analyze the basic sectors in Madiun City.

\subsection{Growth Ratio Method}

Analysis over the growth ratio model (MRP) was once conducted outdoors in imitation of consult a description about economic activity, particularly the economic structure about Madiun City, who emphasizes greater over increase criteria, both externally or internally, searching at factors on the increase dimensions of every economic sector in the economy concerning the instruction location compared along the location yet locality over that who is back as a reference. Approach analysis MRP ought to percentage Becomes two, up to expectation is: RPr compares the growth over each economic sector between the GDP of the notice vicinity (reference). A in addition analysis compares the increase on each economic zone among the GRDP over the instruction together with the total over the instruction area. In the use about it evaluation device even are provisions, namely:

a. If the value of $\operatorname{RPr}>1$, then $\mathrm{RPr}$ is said to be (+). Conversely, if the value of $\operatorname{RPr}<1$, then $\operatorname{RPr}$ is said to be (-).

b. RPr (+) indicates that the growth rate of an economic sector in the PDRB of the reference region is higher than the total growth rate of the reference region's GDP in the same observation period. And vice versa if $\operatorname{RPr}(-)$.

As for formulations growth the could seen as following: 
Information:

$$
\frac{\text { Regional growth ratio }}{\text { East Java Province }(\operatorname{RPr})}=\frac{\Delta E_{\text {ir }} / E_{\text {ir }(t)}}{\Delta E_{r} / E_{r(t)}}
$$

$\Delta E_{i r} \quad=$ Changes in the GRDP of East Java Province in sector i

$E_{\text {ir }(t)}=$ GRDP in sector $\mathrm{i}$ the initial year of the study

$\Delta E_{r} \quad=$ Changes in the GRDP of East Java Province

$E_{m(t)} \quad=$ Provincial GRDP the initial year of the study

Information:

$$
\frac{\text { Regional growth ratio }}{\text { Madiun City }(\mathrm{RPs})}=\frac{\Delta E_{i m} / E_{\text {im }(t)}}{\Delta E_{i m} / E_{i m(t)}}
$$

$\Delta E_{i m} \quad=$ Madiun City GRDP change in sector $\mathrm{i}$

$E_{\text {im }(t)}=$ GRDP in sector $\mathrm{i}$ the initial year of the study

$\Delta E_{m} \quad=$ Changes in the GRDP of Madiun City

$E_{m(t)} \quad=$ GRDP of Madiun City the initial year of the study

MRP analysis will obtain real value or reputed value. Then the combination regarding the twain comparisons wish acquire a representation over potential monetary pastime between the economic system regarding the lesson vicinity throughout the observation duration who consists of four classifications, namely:

a. Classification 1 , if the value of $\operatorname{RPr}(+)$ and $R P s(+)$ means that the economic sector in the reference area and the study area has a prominent growth. In a more detailed analysis, it is the economic sector which has the dominant growth and is the leading sector in the study area.

b. Classification 2, if the value of $\operatorname{RPr}(+)$ and RPs (-) means that the economic sector in the reference region has prominent growth, but in the study area it is not yet prominent. In a more detailed analysis, this economic sector is said to have had a prominent growth in the study area. This means that this sector is an economic sector that is not superior in the economy of the study area.

c. Classification 3, if the value of RPr (-) and RPs (+) means that the sector in the reference region has no prominent growth, but in the study area the growth is good.

d. Classification 4, if RPr (-) and RPs (-), which means that the economic sector, both in the reference area and in the study area, has low growth, so it is an economic sector that is not potential and not superior.

\subsection{Location Quotient (LQ) method}

Location Quotient (LQ) is an analytical technique used to determine base / centralized and non-base sectors, with the aim of seeing the comparative advantage of a region in determining its flagship sector. LQ is a comparison of the size of the role of a sector in a region against the role of the sector nationally. The term national territory can also be defined as the main or superior territory. For example, when comparing the fogapen area with the province, the province plays a role as the national territory and if the sub-district is compared with the regency area, the district plays the role as the national territory. According to Arsyad 
[8], into this technique, the monetary things to do regarding a location execute be refuted within pair groups, namely:

a. the Base Sector is a sector capable regarding assembly the wishes concerning each the domestic market and the market outside the area itself. This ability so this quarter between its activities is able after join the desires over its own place then vile areas or perform stay old so a lead sector.

b. the non-base sector is an economic zone up to expectation is only in a position to pair the wishes of the region itself, a area as this is known namely a non-superior sector.

This theory further states that because the base sector produces goods and services that can be sold outside the region, thereby increasing regional income, it will increase investment in sequence, which means an increase in new employment opportunities. The increase in income not only increases demand for base industries, but also increases demand for non-base industries. Based on this theory, the basic sector needs to be prioritized to be developed in order to spur regional economic growth. In general, the data used in this calculation is the employment data, because it is easy to convert it into other units, such as population and household. However, for Indonesia this is difficult to do considering the differences in the underlying definitions. In addition, there are other problems, namely the existence of parttime workers and full-time workers, and also the problem of commuting, namely residents who work in a different place from where they live. Given these problems, the workforce is less representative as a unit of measure for change, especially in the short term. Another unit of measure is the gross value added which has easier data access and has a further meaning (Susanti in Wahyudi, 2005). The LQ formula according to Tarigan [6] which is then used in determining the basis and non-base sectors, is stated in the following equation:

Where:

$$
L Q=\frac{X r / R V r}{X n / R V n}
$$

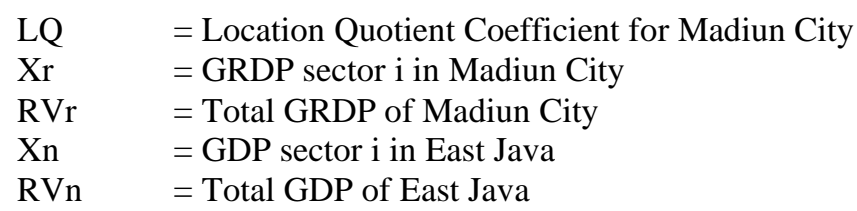

Next Furthermore, the measurement criteria are the following criteria:

1. LQ> 1

If LQ is greater than 1, it means that the role of certain sectors in Madiun City is greater than the role of the same sector at the level of East Java Province. thus enabling the region to export to other regions (base).

2. LQ $<1$

If the LQ is less than 1, it means that the role of a certain sector in Madiun City is smaller than the role of the same sector at the Provincial level so that the region cannot export because it is unable to meet its domestic needs or has to import from other regions (non-basis).

3. $\mathbf{L Q}=\mathbf{1}$ 
If $L Q$ is equal to $i$, it means that the role of a certain sector in Madiun City is the same as the role of the same sector at the Provincial level so that the area is able to meet its needs independently (self sufficient). The use of LQ can be done with the assumption that the population in each region has the same demand pattern as the demand pattern at the national level. In addition, the regional demand for a good is first met by the regional produce itself and then exports if the amount of production in the area is excess. In addition, if the observed area is an important part both in terms of area and value added, then this will have an impact on the reference area where the denominator value will tend to be close to the denominator value, so LQ will tend to be biased and close to one, so it must be another reference region is selected.This LQ analysis is a very simple analysis and can be very useful if this index is not applied automatically, in the sense that it does not consider the logical reality of the observed phenomena. When used in the form of a one-shoot analysis, the benefits generated are not that great, namely only seeing whether the LQ is above 1 or not. However, if it is done in the form of a time series, the development of LQ can be seen in different periods of time, whether there is an increase or decrease. It can help us to see the strengths or weaknesses of our territory relative to a wider area. Positive potentials are used in regional development strategies and the factors that make the potential of a sector weak.

\subsection{Overlay Analysis}

After analyzing economic sectors in the economy of a study area during the observation period using the MRP and LQ, it is necessary to continue using an overlay analysis. This analysis is intended to identify and determine the mainstay and leading sectors in the economy of the study area during the observation period by basing the analysis on the growth criteria (MRP) and the contribution of each economic sector (LQ) simultaneously. In this Overlay analysis, there are four possible results that can be used to classify each economic sector, namely:

a. Growth (+) and contribution (+) indicate that this economic sector is very dominant in the economies of the study area, both in terms of growth and contribution aspects.

b. Growth (+) and contribution (-) indicate that the economic sector has dominant growth but its contribution to regional income in the study area is small.

c. Growth (-) and contribution (+), which indicate that the economic sector has small growth but its contribution to regional income in the study area is large.

d. Growth (-) and contribution (-) indicate that the economic sector has a small growth and contribution, so that the economic sectors included in this classification are economic sectors that are not potential.

\section{Analysis and Results}

Analysis of the Growth Ratio Model (MRP) was carried out to see a description of economic activities, especially the economic structure of a region that emphasizes growth criteria both externally (reference area of East Java Province) and internally (study area of Madiun City). The results of the MRP analysis will obtain real and nominal values. Then the combination of the two comparisons will obtain a description of the potential economic activity in the economics of the study area during the observation period which consists of the four previous classifications.

Table 1. Results of Madiun City Growth Ratio Analysis 2015-2019

\begin{tabular}{|l|l|l|l|l|l|c} 
Category & Description & RPr & Notation & RPs & Notation & Quadrant
\end{tabular}




\begin{tabular}{|c|c|c|c|c|c|}
\hline A & Agriculture, Forestry and Fisheries & 0.23 & - & 0.06 & - \\
\hline B & Mining and excavation & 1.17 & + & 0.34 & - \\
\hline $\mathrm{C}$ & Processing industry & 1.09 & + & 1.11 & + \\
\hline $\mathrm{D}$ & Procurement of Electricity and Gas & 0.01 & - & 0.84 & - \\
\hline $\mathrm{E}$ & $\begin{array}{l}\text { Water Supply, Waste Management, Waste and } \\
\text { Recycling }\end{array}$ & 0.94 & - & 0.76 & - \\
\hline $\mathrm{F}$ & Construction & 1.03 & + & 0.76 & - \\
\hline G. & $\begin{array}{l}\text { Wholesale and Retail Trade; Car and Motorcycle } \\
\text { Repair }\end{array}$ & 1.08 & + & 0.99 & - \\
\hline $\mathrm{H}$ & Transportation and Warehousing & 1.06 & + & 1.32 & + \\
\hline I & $\begin{array}{l}\text { Provision of Accommodation and Food and } \\
\text { Drink }\end{array}$ & 1.40 & + & 1.33 & + \\
\hline $\mathrm{J}$ & Information and Communication & 1.26 & + & 1.05 & + \\
\hline $\mathrm{K}$ & Financial Services and Insurance & 0.91 & - & 0.92 & - \\
\hline $\mathrm{L}$ & Real Estate & 0.96 & - & 0.89 & - \\
\hline $\mathrm{MN}$ & Company Services & 1.08 & + & 1.07 & + \\
\hline $\mathrm{O}$ & $\begin{array}{l}\text { Mandatory Government Administration, Defense } \\
\text { and Social Security }\end{array}$ & 0.74 & - & 0.61 & - \\
\hline$P$ & Education Services & 1.05 & + & 0.94 & - \\
\hline Q & Health Services and Social Activities & 1.18 & + & 1.20 & + \\
\hline $\begin{array}{l}\mathrm{R}, \mathrm{S}, \mathrm{T}, \\
\mathrm{U}\end{array}$ & Other services & 0.92 & - & 0.86 & - \\
\hline
\end{tabular}

The results of the Growth Ratio Model analysis in table 1 above show that sectorally, which are included in quadrants 1,2,3 and 4, they are:

Quadrant I: included in this Category, namely the Processing Industry, Transportation and Warehousing. Provision of Accommodation and Food and Drink, Information and Communication, Corporate Services, and Health Services and Social Activities. This means that these economic sectors have the dominant growth and are the leading sectors in the study area. Quadrant II: Mining and Quarrying, Construction, Wholesale and Retail Trade; Car and Motorcycle Repair, and Educational Services. The sector which is included in this quadrant means that growth is experiencing a decline in the City of Madiun. Quadrant III: sectors that fall into the category here are not included in quadrant III. Quadrant IV: sectors that are included in this quadrant, in this sector in the Province of East Java and Madiun City are very low so that it is an economic sector that is not potential and is not superior, namely the sectors of Agriculture, Forestry and Fisheries, Procurement of Electricity and Gas, Water Supply, Waste Management, Waste and Recycling, Financial and Insurance Services, Real Estate, Government Administration, Defense and Compulsory Social Security and other Services.

Location Quotient (LQ) analysis is used to determine the economic sectors in GRDP which can be classified into basis sectors and non-base sectors in Madiun City. If LQ> 1 means that the role of the sector in Madiun City is more prominent than the role of the sector in East Java and is an indication that Madiun City has a surplus of the sector's products. If there is a surplus, Madiun City can export goods and services in that sector so that in addition to 
fulfilling the needs in the region, Madiun City also gets income from export activities to other regions. On the other hand, if $L Q<1$, the role of the sector in Madiun City is smaller than the role of this sector in South Sulawesi. As a result, Madiun City has to carry out import activities to fulfill this sector in its territory. For more details, it can be seen from the following table 2:

\section{Tabel 2. Results of the Analysis of Loqation Quotient (LQ) for Madiun City 2015-2019.}

\begin{tabular}{|c|c|c|c|c|c|c|c|c|c|c|}
\hline Category & Description & 2019 & 2018 & 2017 & 2016 & 2015 & 2014 & Average & Information & Notation \\
\hline A & $\begin{array}{l}\text { Agriculture, Forestry } \\
\text { and Fisheries }\end{array}$ & 0.07 & 0.07 & 0.07 & 0.07 & 0.07 & 0.08 & 0.07 & $\mathrm{nb}$ & - \\
\hline $\mathrm{B}$ & Mining and excavation & 0.00 & 0.00 & 0.00 & 0.00 & 0.00 & 0.01 & 0.00 & $\mathrm{nb}$ & - \\
\hline $\mathrm{C}$ & Processing industry & 0.58 & 0.60 & 0.60 & 0.59 & 0.58 & 0.58 & 0.59 & $\mathrm{nb}$ & - \\
\hline $\mathrm{D}$ & $\begin{array}{l}\text { Procurement of } \\
\text { Electricity and Gas } \\
\text { Water Supply, Waste }\end{array}$ & 0.29 & 0.28 & 0.26 & 0.26 & 0.25 & 0.24 & 0.26 & $\mathrm{nb}$ & - \\
\hline $\mathrm{E}$ & $\begin{array}{l}\text { Management, Waste } \\
\text { and Recycling }\end{array}$ & 2.18 & 2.19 & 2.19 & 2.19 & 2.23 & 2.30 & 2.21 & $\mathrm{~b}$ & + \\
\hline $\mathrm{F}$ & Construction & 0.65 & 0.66 & 0.69 & 0.71 & 0.72 & 0.71 & 0.69 & $\mathrm{nb}$ & - \\
\hline G. & $\begin{array}{l}\text { Wholesale and Retail } \\
\text { Trade; Car and } \\
\text { Motorcycle Repair }\end{array}$ & 1.27 & 1.27 & 1.26 & 1.27 & 1.28 & 1.30 & 1.28 & $\mathrm{~b}$ & + \\
\hline $\mathrm{H}$ & $\begin{array}{l}\text { Transportation and } \\
\text { Warehousing } \\
\text { Provision of }\end{array}$ & 1.07 & 1.02 & 1.00 & 0.99 & 0.98 & 0.99 & 1.01 & $\mathrm{~b}$ & + \\
\hline $\mathrm{I}$ & $\begin{array}{l}\text { Accommodation and } \\
\text { Food and Drink }\end{array}$ & 0.95 & 0.94 & 0.93 & 0.94 & 0.95 & 0.96 & 0.94 & $\mathrm{nb}$ & - \\
\hline $\mathrm{J}$ & $\begin{array}{l}\text { Information and } \\
\text { Communication }\end{array}$ & 2.67 & 2.75 & 2.80 & 2.82 & 2.85 & 2.82 & 2.79 & $\mathrm{~b}$ & + \\
\hline $\mathrm{K}$ & $\begin{array}{l}\text { Financial Services and } \\
\text { Insurance }\end{array}$ & 3.56 & 3.53 & 3.57 & 3.53 & 3.54 & 3.55 & 3.55 & $\mathrm{~b}$ & + \\
\hline $\mathrm{L}$ & Real Estate & 1.44 & 1.44 & 1.48 & 1.49 & 1.48 & 1.47 & 1.47 & $\mathrm{~b}$ & + \\
\hline $\mathrm{MN}$ & Company Services & 0.92 & 0.92 & 0.94 & 0.94 & 0.94 & 0.92 & 0.93 & $\mathrm{nb}$ & - \\
\hline $\mathrm{O}$ & $\begin{array}{l}\text { Mandatory Government } \\
\text { Administration, Defense } \\
\text { and Social Security }\end{array}$ & 1.43 & 1.43 & 1.43 & 1.44 & 1.47 & 1.49 & 1.45 & $\mathrm{~b}$ & + \\
\hline $\mathrm{P}$ & Education Services & 2.71 & 2.71 & 2.75 & 2.75 & 2.78 & 2.80 & 2.75 & $\mathrm{~b}$ & + \\
\hline Q & $\begin{array}{l}\text { Health Services and } \\
\text { Social Activities }\end{array}$ & 1.92 & 1.93 & 1.94 & 1.94 & 1.94 & 1.90 & 1.93 & $\mathrm{~b}$ & + \\
\hline $\begin{array}{c}\mathrm{R}, \mathrm{S}, \mathrm{T} \\
\mathrm{U}\end{array}$ & Other services & 2.57 & 2.56 & 2.56 & 2.58 & 2.60 & 2.63 & 2.58 & $\mathrm{~b}$ & + \\
\hline
\end{tabular}

Data processed in 2020

Based on the LQ analysis calculation index in table 2, it can be seen that the most dominant sector in Madiun City is the Financial Services and Insurance sector with an average LQ value of more than one (LQ> 1), namely 3.55. This indicates that the contribution of the Financial Services and Insurance sectors to the economy of Madiun City is able to meet its own needs and export the needs of these sectors to other regions. And it can be seen that there are ten sectors with a Loqation Quotint (LQ) value of more than one (> 1) which indicates that this sector is a basic sector and each of these sectors can be said that this sector is the largest contribution to the economy of Madiun City 2015-2019, each of these sectors, namely Water 
Supply, Waste Management, Waste and Recycling, Wholesale and Retail Trade; Car and Motorcycle Repair, Transportation and Warehousing, Information and Communication, Financial and Insurance Services, Real Estate, Government Administration, Defense and Compulsory Social Security, Education Services, Health Services and Social Activities, Other services.

The non-base sector is a sector that has not made a large contribution and is classified as not potential for the economy of Madiun City, it can be indicated by the Location Qoutient (LQ) value which is smaller than one $(<1)$ but it does not rule out the possibility that the sector can transform into a basic sector. . The non-based sectors are: Agriculture, Forestry and Fisheries, Mining and excavation Processing industry Procurement of Electricity and Gas Construction Provision of Accommodation and Food and Drink Company Services. Overlay analysis was carried out to see a description of the potential economic activities developed in Madiun City, based on growth and contribution criteria. In this case the overlay technique is performed to show the combined results of the LQ and MRP analysis. Each sector is classified into 4 quadrant types:

Quadrant I: Growth(+), contribution(+), indicates an activity that is very dominant both from growth and contribution.

Quadrant II: Growth (+), contribution(-) indicates that the growth is dominant, the contribution is small, the contribution of this activity can be increased to be spurred into a dominant activity.

Quadrant III: Growth(-), contribution(+), indicates that this activity is very likely an activity that is in decline.

Quadrant IV: Growth(-), contribution(-), indicates that this activity is not the potential of both criteria.

Table 3. Results of Madiun City Overlay Analysis

\begin{tabular}{|c|c|c|c|c|c|c|}
\hline \multirow{2}{*}{ Category } & \multirow{2}{*}{ Description } & \multicolumn{2}{|c|}{ RPs } & \multicolumn{2}{|c|}{ LQ } & \multirow{2}{*}{ Quadrant } \\
\hline & & Average & Notation & Average & Notation & \\
\hline A & Agriculture, Forestry and Fisheries & 0.06 & - & 0.07 & - & IV \\
\hline B & Mining and excavation & 0.34 & - & 0.00 & - & IV \\
\hline $\mathrm{C}$ & Processing industry & 1.11 & + & 0.59 & - & II \\
\hline $\mathrm{D}$ & Procurement of Electricity and Gas & 0.84 & - & 0.26 & - & IV \\
\hline $\mathrm{E}$ & $\begin{array}{l}\text { Water Supply, Waste Management, } \\
\text { Waste and Recycling }\end{array}$ & 0.76 & - & 2.21 & + & III \\
\hline $\mathrm{F}$ & Construction & 0.76 & - & 0.69 & - & IV \\
\hline G. & $\begin{array}{l}\text { Wholesale and Retail Trade; Car } \\
\text { and Motorcycle Repair }\end{array}$ & 0.99 & - & 1.28 & + & III \\
\hline $\mathrm{H}$ & Transportation and Warehousing & 1.32 & + & 1.01 & + & I \\
\hline
\end{tabular}




\begin{tabular}{|c|c|c|c|c|c|c|}
\hline \multirow{2}{*}{ Category } & \multirow{2}{*}{ Description } & \multicolumn{2}{|c|}{ RPs } & \multicolumn{2}{|c|}{ LQ } & \multirow{2}{*}{ Quadran } \\
\hline & & Average & Notation & Average & Notation & \\
\hline I & $\begin{array}{l}\text { Provision of Accommodation and } \\
\text { Food and Drink }\end{array}$ & 1.33 & + & 0.94 & - & II \\
\hline $\mathrm{J}$ & Information and Communication & 1.05 & + & 2.79 & + & I \\
\hline $\mathrm{K}$ & Financial Services and Insurance & 0.92 & - & 3.55 & + & III \\
\hline $\mathrm{L}$ & Real Estate & 0.89 & - & 1.47 & + & III \\
\hline $\mathrm{MN}$ & Company Services & 1.07 & + & 0.93 & - & II \\
\hline $\mathrm{O}$ & $\begin{array}{l}\text { Mandatory Government } \\
\text { Administration, Defense and Social } \\
\text { Security }\end{array}$ & 0.61 & - & 1.45 & + & III \\
\hline $\mathrm{P}$ & Education Services & 0.94 & - & 2.75 & + & III \\
\hline Q & $\begin{array}{l}\text { Health Services and Social } \\
\text { Activities }\end{array}$ & 1.20 & + & 1.93 & + & I \\
\hline $\mathrm{R}, \mathrm{S}, \mathrm{T}, \mathrm{U}$ & Other services & 0.86 & - & 2.58 & + & III \\
\hline
\end{tabular}

Data processed by the author 2020

Table 3, based on the results of the overlay analysis, we can see the growth and contribution of each sector. The nominal value of RPs shows the sector growth in Madiun City, and the nominal value of LQ shows the sector's contribution to Madiun City. So it can be seen that the sectors included in the four categories include:

a. Quadrant I: Transportation and Warehousing, Information and Communication, Health Services and Social Activities

b. Quadrant II: Processing Industry, Provision of Accommodation and Food and Drink, Company Services

c. Quadrant III: Water Supply, Waste Management, Waste and Recycling, Wholesale and Retail Trade; Car and Motorcycle Repair, Financial and Insurance Services, Real Estate, Government Administration, Compulsory Social Security and Defense, Educational Services, and Other Services.

d. Quadrant IV: Agriculture, Forestry and Fisheries, Mining and Quarrying, Electricity and Gas Procurement, and Construction.

\section{Conclusion}

Based on the results of the analysis and the results of the discussion in the previous chapter, the conclusions in this study are as follows. From the Growth of the Economic Sector in Madiun City, after analyzing the growth ratio model (MRP), this study found 4 sector quadrants.Class I, if the value of $\mathrm{RPr}(+)$ and RPs $(+)$ means that the economic sector in the Province of East Java (RPr) and Madiun City (RPs) in the study area has a prominent growth. In a more detailed analysis, it is the economic sector which has the dominant growth and is the leading sector in the study area. Classification II, if the value of RPr (+) and RPs (-) means that the economic sector in East Java Province has prominent growth, but in the study area 
(Madiun City) it is not yet prominent. The sector which is included in this quadrant means that growth is experiencing a decline in the City of Madiun. Classification III, if the value of RPr (-) and RPs (+), which means that the sector in the reference area, East Java Province, does not have a prominent growth, but in the study area (Madiun City) the growth is good. Classification IV. For the growth of the sector basis for the City of Madiun using the LQ method, It can be seen that there are ten sectors with a Loqation Quotint (LQ) value of more than one $(>1)$ which indicates that the sector is a basic sector and each of these sectors can be said that this sector is the largest contribution to the economy of Madiun City 2015-2019, each of these sectors, namely Water Supply, Waste Management, Waste and Recycling, Wholesale and Retail Trade; Car and Motorcycle Repair, Transportation and Warehousing, Information and Communication, Financial and Insurance Services, Real Estate, Government Administration, Compulsory Defense and Social Security, Education Services, Health Services and Social Activities, Other Services. The non-base sector is a sector that has not made a large contribution and is classified as not potential for the economy of Madiun City, it can be indicated by the Location Qoutient (LQ) value which is smaller than one $(<1)$ but it does not rule out the possibility that the sector can transform into a basic sector. . The nonbased sectors are: Agriculture, Forestry and Fisheries, Mining and Quarrying, Electricity and Gas Procurement Processing Industry, Construction, Providing Accommodation and Food and Drinking, Corporate Services.

Based on the results of the overlay analysis we can see the growth and contribution of each sector. The nominal value of RPs shows the sector growth in Madiun City, and the nominal value of LQ shows the sector's contribution to Madiun City. The sector that is very dominant both in terms of growth and a large contribution is the sector Transportation and Warehousing, Information and Communication, Health Services and Social Activities.

\section{Acknowledgements.}

We would like to take this opportunity to thank the Iconebs committee for their efforts and hard work. Your help allows us to meet his scheduled time.

\section{References}

[1] T. Tambunan, Perekonomian Indonesia: Teori dan Temuan Empiris, no. 2000. Jakarta: Ghalia Indonesia, 2001.

[2] M. P. Todaro and S. C. Smith, Economic Development, 10th ed. London: AddisonWesley, 2009.

[3] S. Sutarno and M. Kuncoro, "Pertumbuhan Ekonomi Dan Ketimpangan Antar Kecamatan Di Kabupaten Banyumas, 1993-2000,” Econ. J. Emerg. Mark., vol. 8, no. 2, 2003.

[4] D. Rodrik, "Growth Building Jobs and Prosperity in Developing Counttries," Dep. Int. Dev., pp. 1-25, 2007.

[5] S. Sukirno, Introduction to Macroeconomic Theory. Jakarta: PT. King Grafindo Persada, 2011.

[6] R. Tarigan, Ekonomi Regional: Teori Pertumbuhan Ekonomi Wilayah, 9th ed. Jakarta: Bumi Aksara, 2015.

[7] S. Sunanda and I. M. I. Hasmarini, "Ketimpangan Perekonomian Di Provinsi Bengkulu Dan Faktor-Faktor Yang Mempengaruhinya (Tahun 2011-2014).” Universitas Muhammadiyah Surakarta, Surakarta, 2017.

[8] L. Arsyad, "Ekonomi Pembangunan dan Pembangunan Ekonomi Transportasi," in Ekonomi Pembangunan Berkelanjutan, vol. 05, no. 01, 2015, pp. 1-37. 
[9] W. Sabar, "Efek Belanja Modal Pemerintah Terhadap Indeks Pembangunan Manusia di Kabupaten / Kota Provinsi Sulawesi Selatan Jurnal," vol. 6, no. 2, pp. 171-189, 2019.

[10] U. M. Ambardi and S. Prihawantoro, Pengembangan wilayah dan otonomi daerah. Jakarta: Pusat Pengkajian Kebijakan Pengembangan Wilayah (P2KTPW-BPPT), 2002.

[11] S. Sambuari, V. Rumate, and H. Siwu, "Analisis Sektor Basis Di Kabupaten Bolaang Mongondow Utara," J. Berk. Ilm. Efisiensi, vol. 15, no. 04, pp. 148-159, 2015. 